\title{
METODE BELAJAR MATEMATIKA (VERSI SAYA)
}

\author{
Yeni Tri Asmaningtias \\ Dosen pada program studi PGMI UIN Malang
}

\begin{abstract}
Learning is not had to use reference books, books dictate, and various books that fit with the material. Learning methods can hear, see or daydreaming the subjects. How to learn something like that could be obtained by seeing or hearing other people's experiences. Experiences can be gained from the other person will create excitement for learning mathematics and foster good mental, especially those are known as leaders in mathematics and other scientists. In addition, the study by first identifying the correct way of learning can encourage understanding how to learn mathematics is good, able to understand the scientific definition, characteristics, and description of mathematics. So that people will not be wrong to choose how to learn, able to know the strategies and methods of mathematics will have an impact also on our favorite mathematics.

Key word: learning, mathematics
\end{abstract}

\section{A. PENDAHULUAN}

Selama ini kita selalu mengatakan bahwa matematika adalah suatu mata pelajaran yang sulit dipahami oleh peserta didik, selalu ditakuti, bahkan ada yang menjadikan mata pelajaran ini sebagai momok, bisa dikatakan bahwa matematika selalu "dikambinghitamkan" oleh peserta didik, guru, yang memang tidak suka dengan mata pelajaran matematika. Uraian diatas tidaklah salah karena memang pada kenyataannya hasil survey pengukuran dan penelitian pendidikan oleh The Third International Mathematics and Science Study-Repeat (TIMSS-R) menyebutkan bahwa pengetahuan dan kemampuan anak Indonesia bidang matematika sangat rendah. Padahal jika kita lihat lagi matematika sangat berperan dalam kehidupan sehari-hari, salah satu contohnya adalah penghitungan pada transaksi jual beli di pasar sampai penghitungan bahasa mesin pada komputer, dari hal-hal yang sangat sederhana sampai pada hal-hal yang sangat kompleks. Matematika juga berperan sangat penting dalam 
persiapan untuk memberi bekal agar dapat berfungsi secara efektif dalam zaman teknologi pada setiap aspek kehidupan bersama. Dan tidak menyisihkan disiplin ilmu yang lain, matematika sekarang memberikan sumbangan langsung dan mendasar terhadap bisnis, ekonomi, kesehatan, pertahanan, dan masih banyak lagi.

Untuk menyelaraskan argumentasi yang "pro" terhadap matematika dan yang "kontra" terhadap matematika, penulis ingin memberikan sedikit pengalaman tentang bagaimana menciptakan suasana "senang" kepada peserta didik dan guru yang mengajar.

Pada waktu sekolah (SD, SMP, dan SMA) penulis paling tidak suka dengan mata pelajaran matematika karena matematika dianggap sebagai symbol yang kita tidak tahu maknanya itu apa, ketika SD penulis merasakan bahwa belajar matematika adalah belajar yang paling menyiksa fisik dan mental, karena setiap kali belajar matematika penulis harus mendapatkan siksaan berupa pukulan disebabkan oleh ketidaktauhan penulis dalam mengerjakan matematika, saat SMP penulis mulai merasa senang dengan pelajaran matematika karena waktu itu guru matematikanya ganteng, penulis suka matematika karena gurunya bukan karena matematikanya, masuk SMA penulis merasakan ketidaksukaan kembali kepada matematika karena penilaian guru matematika tidak adil, yang ikut les di rumahnya pasti mendapatkan nilai yang bagus, sedangkan yang tidak ikut les di rumahnya meskipun nilai ulangannya bagus tetapi nilai di sekolah tetap saja tidak bagus, hal inilah yang menyebabkan penulis tidak menyukai matematika lagi, selain pelajarannya yang tambah sulit dan tambah tidak dimengerti, kemudian setelah lulus SMA, penulis terjebak oleh situasi yang mewajibkan penulis untuk senang terhadap matematika karena penulis kuliah di jurusan matematika karena ketidaktauhan penulis melihat brosur yang ada di salah satu pamphlet yang dipasang oleh universitas tersebut. Di awal perkuliahan terasa sangat menjemukan, memuakkan, bahkan hampir putus asa untuk pindah di jurusan yang lain yang sesuai dengan kemampuan dan hati nurani, tetapi setelah di akhir-akhir perkuliahan, penulis menemukan keasyikan dalam mempelajari matematika, keasyikan yang membawa penulis melanjutkan ke jenjang magister matematika, dan dari magister matematika tersebut penulis menemukan beberapa cara mempelajari matematika dengan mudah supaya matematika tidak dianggap lagi sebagai pelajaran yang sulit. Cara pembelajaran inilah yang akan penulis ceritakan untuk 
Yeni Tri asmaningtias-Metode belajar matematika

dijadikan sebagai salah satu bentuk pembelajaran yang mungkin bisa digunakan oleh siapa saja yang berminat terhadap matematika.

\section{B. PEMBAHASAN}

Pertama penulis memberikan ilustrasi tentang sejarah tokoh-tokoh matematika dan karakteristiknya, karena dengan mengetahui sejarah tokoh-tokoh matematika, ada kemungkinan kita merasa tergerak untuk meniru hal-hal yang positif dari tokoh-tokoh matematika tersebut.

\section{A. Sejarah Tokoh-tokoh matematika}

Trachtenberg mempertaruhkan jiwanya menentang Hitler. Trachtenberg, setelah menyelami prinsip-prinsip matematika, menyimpulkan bahwa prinsip kehidupan adalah keharmonisan. Peperangan yang terus berkobar, menyulut kebencian tidak sesuai dengan prinsip-prinsip matematika. Matematika adalah keindahan. Atas penentangannya ini, Hitler menghadiahi Trachtenberg hukuman penjara. Bagi Trachtenberg, perjara bukan apa-apa. Di dalam penjara, dia justru memiliki kesempatan memikirkan matematika tanpa banyak gangguan. Karena sulit mendapatkan alat tulis-menulis, Trachtenberg mengembangkan pendekatan matematika yang berbasis mental-imajinasi.

Seribu tahun sebelum itu, AlKhawaritzmi mengembangkan disiplin matematika baru: aljabar. AlKharitzmi beruntung hidup dalam lingkungan agama Islam yang kuat. Ajaran Islam, secara inheren, menuntut keterampilan matematika tingkat tinggi. Misalnya, Islam menetapkan aturan pembagian waris yang detil. Pembagian waris sistem Islam melibatkan banyak variabel matematis. Variabel-variabel yang beragam ini menantang penganut Islam - termasuk AlKhawaritzmi - untuk mencari pemecahan yang elegan. Pemecahan terhadap sistem persamaan yang melibatkan banyak variabel ini membawa ke arah disiplin baru matematika: aljabar. AlKhawaritzmi menulis buku khusus tentang aljabar yang sangat fenomenal. Buku yang berjudul Aljabar ini menjadi panutan bagi matematikawan seluruh dunia. Sehingga nama AlKhawaritzmi menjadi dikenal sebagai Aljabar AlKhawaritzmi (Algebra Algorithm).

Sistem kalender Islam yang berbasis pada komariah (bulan, lunar) memberikan tantangan tersendiri. Penetapan awal bulan menjadi krusial di dalam Islam. Berbeda dengan kalender syamsiah (matahari, solar). Dalam kalender syamsiah, kita tidak begitu sensitif apa berbedaan tanggal 1 Juni dengan 2 Juni. Tetapi pada sistem komariah, perbedaan 1 Ramadhan denga 
Yeni Tri asmaningtias-Metode belajar matematika

2 Ramadhan berdampak besar. Itulah sebabnya, astronomi Islam dapat maju lebih awal. Astronomi memicu lebih berkembangnya teori trigonometri. Aturan sinus, cosinus, dan kawan-kawan berkembang pesat di tangan para astronom Islam waktu itu.

Dengan mengetahui sejarah dari tokoh-tokoh matematika, maka kita akan sediikit tergerak untuk lebih mempelajarai matematika, memahami dan mau memperdalam matematika.

B. Identifikasi cara belajar matematika

Beberapa orang belajar matematika hanya untuk kesenangan. Beberapa orang yang lain belajar karena kewajiban. Ada pula yang belajar matematika agar naik jabatan. Ada juga agar lulus UN, SPMB, UMPTN. Ada juga untuk menjadi juara. Masing-masing tujuan, berimplikasi kepada cara belajar matematika yang berbeda. Misalnya bila belajar matematika untuk kepentingan lulus UN, SPMB, UMPTN 2008 akan berbeda dengan belajar untuk memenangkan olimpiade matematika. Matematika UN, SPMB, UMPTN 2008 hanya menerapkan soal pilihan ganda. Implikasinya hanya dinilai dari jawaban akhir. Proses menemukan jawaban tidak penting. Jadi harus memilih siasat yang cepat dan tepat. Gunakan berbagai macam rumus cepat dalam matematika. Rumus cepat ampuh digunakan untuk UN, SPMB, UMPTN. Tetapi rumus cepat matematika tidak akan berguna untuk olimpiade atau kuliah kalkulus kelak di perguruan tinggi. Contoh rumus cepat matematika yang sering (hampir selalu) berguna ketika UN, SPMB, UMPTN adalah rumus tentang deret aritmetika.

\section{Contoh soal:}

Jumlah $n$ suku pertama dari suatu deret a dalah $S n=3 n^{\wedge} 2+n$. Maka suku ke-11 dari deret tersebut adalah...

Tentu ada banyak cara untuk menyelesaikan soal ini.

Cara pertama, tentukan dulu rumus Un kemudian hitung U11. Cara ini cukup panjang. Tetapi bagus dicoba untuk meningkatkan keterampilan dan pemahaman konsep deret. Rumus Un dapat kita peroleh dari selisih Sn $-S(n-1)$.

Cara kedua, sedikit lebih cerdik dari cara pertama. Kita tidak perlu menentukan rumus Un. Karena kita memang tidak ditanya rumus tersebut. Kita langsung menghitung U11 dengan cara menghitung selisih

$\mathrm{S} 11-\mathrm{S} 10=\mathrm{U} 11$

$\left[3\left(11^{\wedge} 2\right)+11\right]-\left[3\left(10^{\wedge} 2\right)+10\right]$ 
Yeni Tri asmaningtias-Metode belajar matematika

$$
\begin{aligned}
& =3.121-3.100+11-10 \\
& =3.21+1 \\
& =64
\end{aligned}
$$

Cara ketiga, adalah rumus matematika paling cepat dari kedua rumus di atas. Tetapi sebelum menerapkan cara ketiga, kita harus memahami konsepnya terlebih dahulu dengan baik.

Bentuk baku dari $\mathrm{n}$ suku pertama deret aritmetika adalah

$$
\begin{aligned}
& \mathrm{Sn}=(\mathrm{b} / 2) \mathrm{n}^{\wedge} 2+\mathrm{k} \cdot \mathrm{n} \\
& \mathrm{Un}=\mathrm{b}(\mathrm{n}-1)+\mathrm{a} \\
& \mathrm{a}=\mathrm{S} 1=\mathrm{U} 1
\end{aligned}
$$

Dengan hanya melihat soal (tanpa menghitung di kertas) bahwa

$$
\mathrm{Sn}=3 \mathrm{n}^{\wedge} 2+\mathrm{n}
$$

Kita peroleh

$$
\begin{aligned}
\mathrm{b} & =6(\text { dari } 3 \times 2) \\
\mathrm{a} & =4(\text { dari } \mathrm{S} 1=3+1) \\
\mathrm{U} 11 & =6.10+4=64 \text { (Selesai) }
\end{aligned}
$$

Semua perhitungan di atas dapat kita lakukan tanpa menggunakan alat tulis. Semua kita lakukan hanya dalam imajinasi kita.

Anda termasuk yang mana???

C. Matematika itu apa?

Jika kita seringkali dihadapkan oleh pertanyaan seperti diatas, seringkali juga jawaban dari pertanyaan itu adalah matematika adalah angka atau yang berhubungan dengan angka, bagaimana jika ada variabel di dalam matematika? Ada $x, y$, apakah hal tersebut termasuk matematika atau bukan?

Jika kita dihadapkan pada pertanyaan diatas, maka jawaban yang pantas adalah matematika itu luas, matematika tidak terfokus pada angka dan variabel saja, karena begitu banyak cabang matematika dan begitu luas lapangan garapnya untuk menjawab secara detail matematika itu apa, maka jawabannya bisa dijawab dengan mendeskripsikan beberapa sifatnya saja.

Sebelum mendeskripsika beberapa sifat dan karakteristik matematika yang meliputi: karakteristik matematika dan deskripsi matematika maka didefinisikan terlebih dahulu definifi dari matematika itu sebagai apa. Matematika merupakan buah pikir manusia yang kebenarannya bersifat umum (deduktif). Kebenarannya tidak tergantung pada metode ilmiah yang mengandung proses induktif. Kebenaran matematika pada dasarnya bersifat koheren. Contoh kebenaran dalam 
matematika: Pernyataan matematika $3+3=6$ (dalam system decimal) bernilai benar. Hal ini diperoleh menurut pikiran logis kita bahwa tiga ditambah tiga sudah pasti enam.

Matematika juga merupakan hasil dari pemikiran manusia yang dihasilkan dari persoalan pemikiran maupun dari persoalan yang menyangkut kehidupan nyata sehari-hari. Disamping sebagai hasil dari pemikiran, matematika dapat pula dipandang sebagai proses berpikir itu sendiri (logika). Contoh dalam deret Keluarga Ahmadi memiliki 5 orang anak. Saat ini, usia kelima anak tersebut membentuk barisan aritmetika. Jika usia anak ke-3 adalah 12 tahun dan usia anak ke-5 adalah 7 tahun, tentukan jumlah usia kelima anak tersebut. Tanpa perlu bertanya langsung kepada keluarga Ahmadi, matematika bisa langsung menjawabnya.

Jawab:

Dengan memodelkan permasalahan tersebut, diperoleh

$$
\begin{aligned}
& n=5 \\
& U 3=12=a+2 b \ldots(1) \\
& U 5=7=a+4 b \ldots(2) \\
& 5=-2 b \\
& b=-2,5
\end{aligned}
$$

Dengan menyubstitusikan $b=-2,5$ ke persamaan (1), diperoleh

$$
\begin{aligned}
& a+2 b=12 \\
& a+2(-2,5)=12 \\
& a-5=12 \\
& a=12+5=17
\end{aligned}
$$

Dengan demikian,

$$
\begin{aligned}
& S 5=5 \\
& 2(2 a(51) b)=5
\end{aligned}
$$$$
2(2174(-25))=5
$$$$
2(34-10)=60
$$

Jadi, jumlah usia kelima anak tersebut adalah 60 tahun.

Dengan mengetahui definisi dari matematika secara jelas, kita akan tahu bahwa matematika bukan hanya berisi angka-angka dan perhitungan saja tetapi lebih dari itu.

c. 1. Matematika sebagai Proses

Contoh-contoh berikut mengilustrasikan matematika sebagai proses atau memainkan peran penting dalam proses beerpikir.

Zaenal dan Yeni membeli jenis pensil dan pulpen yang sama. Zaenal membeli 2 pensil dan sebuah pulpen dan membayar Rp. 1.400,00. Sedang 
Yeni membayar Rp. 2.575,00 untuk membeli 3 pensil dan 2 pulpen. Bagaimana setiap orang dapat mengetahui berapa harga masing-masing pensil dan pulpen? (tanpa harus bertanya kepada Zaenal dan Yeni atau took yang menjual).

Kita lihat penyelesaian ini dengan menggunakan matematika.

Misalkan pensil dan pulpen yang dibeli Zaenal dua kali, yaitu 4 pensil dan 2 pulpen, maka dia harus membayar dua kali lipat, yaitu Rp. 2.800,00. Misalkan pula dari 4 pensil dan 2 pulpen Zaenal tersebut dikembalikan 3 pensil dan 2 pulpen, maka yang tersisa adalah sebuah pensil saja. Karena harga 3 pensil dan 2 pulpen Rp. 2.575,00, maka harga sebuah pensil tersebut adalah $2.800-2.575=225$ rupiah. Selanjutnya harga 2 pensil menjadi Rp. 450,00. Karena itu harga sebuah pulpen adalah $1.400-450=$ 950 rupiah. Walaupun proses penyelesaian tersebut merupakan kegiatan matematis, tetapi kita dapat pula menggunakan symbol matematika agar lebih efisien.

Misalkan harga sebuah pensil $=a$ dan harga sebuah pulpen $=b$, maka proses diatas dinyatakan sebagai berikut:

$$
\begin{aligned}
& 1.400=2 a+b==>x 2==>2.800=4 a+2 b \\
& 2.575=3 a+2 b==>x 1==>2.575=3 a+2 b- \\
& 225=a \\
& 1.400=2(225)+b==>b=1.400-450=950
\end{aligned}
$$

c.2. Matematika sebagai Produk

Matematika adalah produk dari pemikiran intelektual manusia. Pemikiran intelektual itu bisa didorong dari persoalan pemikiran belaka maupun dari persoalan yang menyangkut kehidupan nyata sehari-hari.

Contoh:

Bilangan dapat dikatakan sebagai produk pemikiran manusia. Bilangan asli dipercaya muncul karena kebutuhan manusia untuk mengetahui jumlah hewan yang dimiliki manusia kuno. Sementara bilangan imajiner (bilangan khayal) muncul karena kebutuhan manusia untuk memberi arti pada penyelesaian suatu masalah yang murni bersifat pemikiran belaka (matematis). Contohnya, bilangan yang menjadi penyelesaian $x^{2}+1=0$. Contoh lain adalah bilangan prima, juga merupakan produk pemikiran belaka. 
Yeni Tri asmaningtias-Metode belajar matematika

\section{KARAKTERISTIK DAN DESKRIPSI MATEMATIKA}

Obyek-obyek matematika bersifat social-kultural-historis yang artinya bahwa matematika dan pembelajarannya merupakan milik bersama seluruh umat, matematika adalah bagian dari kebudayaan karena itu matematika bersifat universal yang lahir dari perjalanan panjang dalam kehidupan manusia itu.

Karena matematika lahir dari perjalana panjang kehidupannya dan matematika merupakan bagian dari kebudayaan manusia tersebut maka matematika mempunyai sisi yang tidak terpisahkan yaitu sejarah. Sejarah matematika termasuk bagian dari matematika, sejarah matematika dapat memberikan pengaruh kepada perkembangan matematika dan pembelajaran matematika. Matematika "diciptakan" oleh manusia terdahulu, maka dengan adanya "penciptaan" matematika ini mengilhami pembelajaran yang bersifat konstruktivisme. Peserta didik diperbolehkan menggunakan usahanya sendiri dalam menyelesaikan suatu masalah matematika.

Dengan adanya sejarah matematika, maka akan menimbulkan kegairahan untuk mempelajari matematika dan menumbuhkan mental yang baik, oleh sebab itu penulis memaparkan beberapa biografi matematikawan yang dikutip dari buku Carl B. Boyer, buku Howard Eves, serta Web karya O'Connor, J. J. \& Robertson, E. F., sebagai berikut:

a. Biografi Euler (1707 - 1783)

Leonhard Euler, tokoh matematika yang dominan dari abad kedelapan belas dan pengarang matematika paling subur sepanjang masa. Lahir dekat Basel, Swiss, ia telah menerbitkan makalah-makalah pada usia 18 tahun. Ia menjabat di Universitas Basel, St. Petersburg Academy of Science. Pada waktu ia meninggal, disebutkan bahwa semua matematikawanEropa adalah muridnya.

Euler memulai karya lewat publikasi dan beberapa artikel dalam bukunya "Mechanica" (1736 - 1737). Pada tahun 1741 di Berlin ia telah menulis lebih dari 200 artikel, 3 buku tentang analisis matematika, serta publikasi ilmiah popular "Letter to a Princess of Germany" (3 volume, 1768 - 1772).

Minat Euler terdapat di semua matematika dan fisika. Ia memperkenalkan e sebagai bilangan dasar untuk logaritma asli/natural pada tahun 1727, memperkenalkan bahwa $e$ dan $e^{2}$ adalah tak rasional (irasional), memperkenalkan $i$ untuk akar kuadrat dari -1 tahun 1777, lambang $\Pi$, lambang $\Sigma$ di tahun 1755, dan menemukan hubungan luar biasa $e^{i \pi}+1=0$. 
Euler juga memperkenalkan " $f(x)$ " pada tahun 1734, memperkenalkan fungsi Beta dan Gamma, serta factor integrasi untuk persamaan differensial.

Kebutaan selama 17 tahun terakhir dari hidupnya dimulai pada usia 31 tahun, nampaknya tidak menghambat karirnya. Sebagian disebabkan oleh daya ingatnya yang luar biasa, ia mengetahui dalam hati rumus-rumus trigonometri dan analisis, ditambah banyak puisi. Dikatakan bahwa ia telah mengerjakan suatu perhitungan sampai 50 tempat decimal di dalam kepalanya. Sampai usia 48, tokoh matematika ini telah menghasilkan 886 buku dan artikel.

Euler adalah seorang yang sangat baik hati dan guru teladan. Ketika mengetahui seorang muridnya, Lagrange bisa menemukan sebuah teori matematika (yang sebenarnya telah ia temukan), ia menahan diri agar muridnya yang mempublikasikan terlebih dahulu hasil temuan tersebut. Ia juga pecinta keluarga, yang seringkali menghabiskan waktu sorenya dengan membangun permainan-permainan ilmiah dan membaca kitab suci untuk 13 putra-putrinya. Ia seorang yang mengagumkan.

b. Sejarah Determinan (dapat menjadi pengantar pembelajaran)

Perkembangan konsep determinan muncul lebih dulu sebelum konsep matriks. Ini dikarenakan konsep determinan terkait dengan penyelesaian sistem persamaan. Ide determinan muncul pertama kali di Jepang dan di Eropa pada waktu yang hampir bersamaan, tetapi Seki Kowa mempublikasikan terlebih dahulu di Jepang pada tahun 1683. Seki menulis buku Method of Solving the Dissimulated problems yang memuat metode matriks. Tanpa menggunakan istilah apapun untuk "determinan", ia memperkenalkan determinan dan memberikan metode umum untuk menghitungnya. Seki menemukan determinan untuk matriks ordo $2 \times 2,3$ x 3, 4 x 4, 5 x 5, dan menggunakannya untuk menyelesaikan persamaan pangkat tinggi, bukan sistem persamaan.

c. Sejarah mengenai penggunaan angka romawi dan hindu-arab

Sistem perhitungan Romawi tidak mengenal nilai tempat dan tidak mengenal angka nol. Padahal nilai tempat sangat berguna untuk menulis bilangan yang sangat besar, sedangkan angka nol berguna untuk menyatakan pecahan decimal.

Contoh penggunaan nilai tempat:

1. Menuliskan bilangan 80.249 dengan angka romawi, Coba juga dituliskan 21.433 .000 (tidak ada angka romawi untuk bilangan seperti ini) 
2. Dalam menjumlah suatu bilangan, kita harus memperhatikan angka yang nilai tempatnya sama, contoh: $3.254+879,3$ ribuan 2 ratusan 5 puluhan 4 satuan ditambah dengan 8 ratusan 7 puluhan 9 satuan (angka romawi tidak mengenal nilai tempat).

d. Sejarah Perkembangan konsep fungsi trigonometri

Penggunaan fungsi trigonometri bermula sebagai hubungan antara matematika dan astronomi, sehingga trigonometri pada awalnya berkenaan dengan trigonometri bola (sperichal trigonometry). Bila diberikan sebuah lingkaran yang berjari-jari 60, maka masalahnya adalah mencari panjang tali busur dihadapan suatu sudut pusat. Tabel tali busur yang pertama dikenal dari Hipparchus (k. 180-k.125 SM) sekitar 140 SM tetapi bukunya sendiri telah hilang.

Pemakaian setengah tali busur dalam notasi modern berarti menunjukkan nilai sinus dimulai dari India. Dalam karya Aryabhata I, sekitar $500 \mathrm{M}$, terdapat table setengah tali busur dengan menggunakan nama "jya". Tabel yang serupa juga dihasilkan oleh Brahmagupta tahun 628 dan Bhaskara II (1114-k.1185) pada tahun 1150.

Al-Battani atau dikenal di Eropa sebagai Albatenius (k.858-929) memberikan rumusan yang menghasilkan sebuah daftar fungsi kotangens untuk setiap derajat sudut. Abu al-wafa' orang yang pertama kali menggunakan fungsi tangens dalam tabel. Dia juga memperkenalkan fungsi sekan dan kosekan serta membahas hubungan antara keenam fungsi trigonometri dengan lewat sebuah busur.

Studi tentang trigonometri sebagai ilmu matematika, lepas dari astronomi pertama kali diberikan oleh Nashiruddin al-tusi (1201-1274), lewat bukunya Treatise on the quadrilateral. Bahkan dalam bukunya untuk pertama kali memperlihatkan keenam fungsi trigonometri lewat sebuah segitiga siku-siku.

Konsep tangen dan kotangen lahir dengan jalur yang berbeda dengan sinus dan kosinus. Konsep tangen dan kotangen pada awalnya tidak berhubungan langsung dengan sudut, tetapi berasal dari perhitungan tinggi menggunakan panjang bayangan matahari (studi gnomonic). Di Arab studi ini dikenal dengan nama studi gnomon, suatu bagian alat penunjuk waktu dengan bantuan sinar matahari, dan mulai muncul oleh matematikawan Arab sekitar 860. Kedua istilah Arab zill dan zill-makus diterjemahkan ke latin menjadi umbra dan umbra versa. Konsep sekan dan kosekan pun lahir dari studi tentang gnomon ini. 
Tahun 1533 Johann Muler (1436 - 1476) menerbitkan buku De triangulis omnimodis yang dipercaya beberapa sejarawan sebagai buku lengkap pertama yang membahas trigonometri bidang. Tabel-tabel trigonometri pada awalnya banyak berhubungan dengan sinus dan tangen karena kosinus dan kotangen serta lainnya dapat langsung diperoleh dari tabel sinus dan tangen.

\section{E. STRATEGI PEMBELAJARAN MATEMATIKA}

Pada dasarnya, tugas utama seorang guru matematika adalah membantu siswanya mendapatkan informasi, ide-ide, keterampilanketerampilan, nilai-nilai, dan cara-cara berpikir serta cara-cara mengemukakan pendapat. Namun tugas yang paling utama dari para guru matematika di SD adalah membimbing para siswa tentang bagaimana belajar yang sesungguhnya serta bagaimana belajar memecahkan masalah sehingga hal-hal tersebut dapat digunakan di masa depan mereka, di saat mereka sudah meninggalkan bangku sekolah lalu terjun ke lapanganlapangan kerja yang sesuai.

Tujuan jangka panjang pembelajaran matematika adalah untuk meningkatkan kemampuan para siswa agar mereka mampu mengembangkan diri mereka sendiri dan mampu memecahkan masalah yang muncul, untuk itu, di samping dibekali dengan pengetahuan dan keterampilan matematis, mereka sudah seharusnya dibekali juga dengan kemampuan untuk belajar mandiri dan belajar memecahkan masalah.

Sejalan dengan munculnya teori belajar terbaru yang dikenal dengan konstruktivisme, menguatnya isu demokratisasi pendidikan, semakin canggihnya teknologi informasi dan komunikasi, semakin dibutuhkannya kemampuan memecahkan masalah dan berinvestigasi, dan semakin banyak dan cepatnya penemuan teori-teori baru, maka pendekatan seperti Pendidikan Matematika Realistik (Realistic Mathematics Education), Pembelajaran Berbasis Pemecahan Masalah (Problem Based Learning), Pembelajaran Kooperatif (Cooperative Learning), serta Pendekatan Pembelajaran Matematika Kontekstual (Contextual Teaching \& Learning) merupakan pendekatan-pendekatan yang sangat dianjurkan para pakar untuk digunakan selama proses pembelajaran di kelas-kelas di Indonesia.

Dengan strategi pembelajaran baru ini, diharapkan adanya perubahan dari: 
1. Mengingat (memorizing) atau menghafal (rote learning) ke arah berpikir (thinking) dan pemahaman (understanding)

2. Model ceramah ke pendekatan: discovery learning, inductive learning, atau inquiry learning.

3. Belajar individual ke kooperatif.

4. Positivist (behaviorist) ke konstruktivisme, yang ditandai dengan perubahan paradigma pembelajaran, dari paradigma pengetahuan dipindahkan dari otak guru ke otak siswa (knowledge transmitted) ke bentuk interaktif, investigatif, eksploratif, open ended, keterampilan proses, modeling, ataupun pemecahan masalah.

5. Subject centred ke clearer centred (terkonstruksinya pengetahuan siswa). Karena itulah pendekatan dan strategi pembelajaran yang dapat disarankan adalah suatu pendekatan yang didasarkan pada suatu pendapat bahwa pemahaman suatu konsep atau pengetahuan haruslah dibangun sendiri (dikonstruksi) oleh siswa.

Contoh Pembelajaran Berbasis Konstruktivisme

Berikut ini adalah contoh pembelajaran pengurangan dasar bilangan. Alternatif rancangan proses pembelajaran ini dapat saja disempurnakan dan disesuaikan dengan kondisi daerah dan keadaan siswa.

Langkah-langkah proses pembelajarannya adalah sebagai berikut:

1. Pada tahap awal, Guru mengajukan masalah seperti berikut di papan tulis, di transparansi, ataupun di kertas peraga.

Ardi memiliki 12 kelereng.

9 kelereng diberikan kepada adiknya.

Berapa kelereng yang dimiliki Ardi sekarang?

2. Guru bertanya kepada para siswa, berapa kelereng yang dimiliki Ardi pada awalnya? Jawaban yang diinginkan adalah 12. Guru lalu menggambar di papan tulis, 12 buah kelereng seperti gambar di bawah ini dengan menekankan bahwa 12 bernilai 1 puluhan dan 2 satuan atau $12=10+2$.

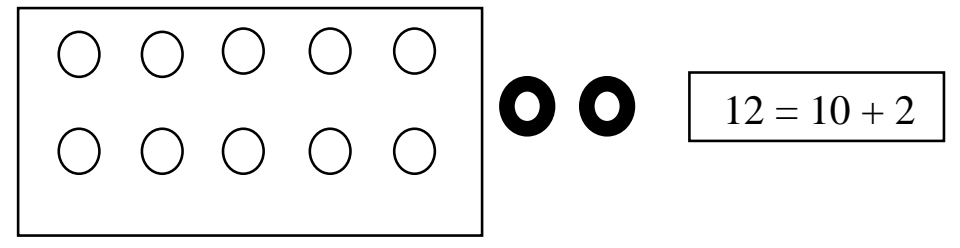


3. Guru meminta siswanya bekerja dalam kelompok dengan menggunakan benda-benda konkret yang dimilikinya untuk menggambarkan 12 kelereng yang dimiliki Ardi.

4. Guru bertanya kepada siswa, berapa butir kelereng yang diberikan kepada adiknya dan berapa sisa kelereng yang dimiliki Ardi sekarang? Biarkan siswa bekerja sendiri-sendiri atau bekerja di kelompoknya untuk menjawab soal tersebut.

5. Ada dua kemungkinan jawaban siswa atau kelompok siswa, seperti yang terlihat pada gambar di bawah ini. Pada waktu diskusi kelompok, Bapak atau Ibu Guru sebaiknya menawarkan alternatif kedua ini kepada beberapa kelompok.

(1)

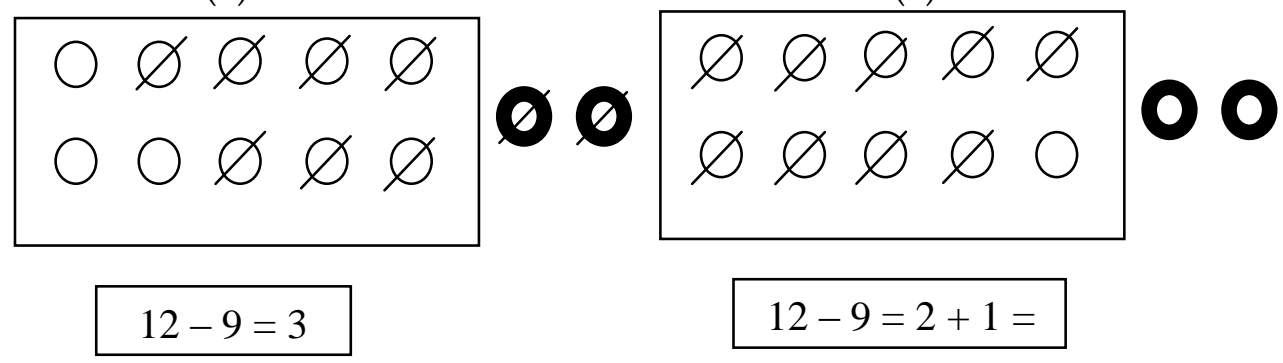

6. Guru memberi kesempatan kepada siswa atau kelompok untuk melaporkan cara mereka mendapatkan hasilnya. Diskusikan juga, yang mana dari dua cara tersebut yang lebih mudah digunakan.

7. Guru memberi soal tambahan seperti 13-9 dan 12-8. Para siswa masih boleh menggunakan benda-benda konkret. Bagi siswa yang masih menggunakan alternatif pertama, sarankan untuk mencoba alternatif kedua dalam proses menjawab dua soal di atas.

8. Guru memberi soal tambahan seperti 14-9 dan 13-8. Bagi siswa atau kelompok siswa yang sudah dapat menyelesaikan soal ini tanpa menggunakan benda konkret dapat mengerjakan soal-soal yang ada di buku.

Belajar Arti Konstruktivisme dari Contoh di Atas

Dari contoh proses pembelajaran pengurangan di atas dapat dikemukakan beberapa hal berikut:

1. Peran guru sebagai fasilitator dalam membantu siswanya dapat dengan mudah melakukan operasi pengurangan dasar bilangan. Dengan cara 
seperti ini, pengetahuan diharapkan dapat dengan mudah terkonstruksi atau terbangun di dalam pikiran siswanya.

2. Dengan alternatif rancangan pembelajaran seperti itu, para siswa sendirilah yang harus membangun pengetahuan bahwa $12-9=2+1,13$ $-9=3+1,12-8=2+2,14-9=4+1$, dan seterusnya.

3. Para siswa juga dibimbing gurunya untuk secara demokratis menentukan pilihan-pilihan, dan secara dini belajar untuk menghargai pendapat teman lainnya meskipun berbeda dengan pendapatnya sendiri.

4. Dengan alternatif rancangan pembelajaran seperti itu, ketika para siswa diminta menentukan hasil dari 15 - 8 misalnya, di dalam pikiran siswa akan muncul gambaran (sebagai hasil pengalaman belajar di kelasnya), kelereng sejumlah 1 puluhan dan 5 satuan yang jika diambil 8 akan menghasilkan $5+2=7$.

5. Pengalaman belajar yang dirancamg ini tidak akan berhasil jika siswa tidak atau kurang terampil menentukan hasil $10-9=1,10-8=2,10-7$ $=3$ dan seterusnya. Hal ini menunjukkan benarnya pendapat Ausubel, penggagas belajar bermakna (meaningful learning) yang menyatakan hal berikut sebagaimana dikutip Orton (1987:34): If I had to reduce all of educational psychology to just one principle, I would say this: The most important single factor influencing learning is what the learner already knows. Ascertain this and teach him accordingly." Jelaslah bahwa pengetahuan yang sudah dimiliki siswa akan sangat menentukan berhasil tidaknya suatu proses pembelajaran.

6. Proses pembelajaran ini sesungguhnya didasarkan pada suatu keyakinan dari para penganut konstruktivisme yang menyatakan bahwa suatu pengetahuan tidak dapat dipindahkan dari otak seorang guru dengan begitu saja ke dalam otak siswa. Siswa sendirilah, yang dengan bantuan guru, akan dapat menemukan kembali pengetahuan yang sudah ditemukan para ahli matematika.

7. Dengan fasilitasi dari para guru matematika sebagaimana dinyatakan para pakar pendidikan matematika, prosedur pengurangan dasar bilangan seperti 12-9 maupun 13-8 ditemukan kembali (guided reinvention) si pembelajar seperti ketika para siswa menemukan kembali rumus, konsep, ataupun prinsip seperti yang ditemukan para matematikawan. 
Berdasar penjelasan dan contoh di atas, implikasi konstruktivisme pada pembelajaran di antaranya adalah:

1. Usaha keras seorang guru dalam mengajar tidak mesti diikuti dengan hasil yang bagus pada siswanya. Setiap siswa SD harus mengkonstruksi (membangun) pengetahuan matematika di dalam benaknya masingmasing berdasar pada kerangka kognitif yang sudah ada di dalam benaknya. Karenanya, hanya dengan usaha keras para siswa sendirilah para siswa akan betul-betul memahami Matematika. Setiap guru matematika SD tentunya sudah mengalami bahwa meskipun suatu materi telah dibahas dengan sejelas-jelasnya namun masih ada sebagian siswanya yang belum ataupun tidak mengerti materi yang diajarkannya. Hal ini telah menunjukkan bahwa seorang guru dapat mengajar suatu materi kepada siswanya dengan baik, namun seluruh atau sebagian siswanya tidak belajar sama sekali.

2. Tugas setiap guru adalah memfasilitasi siswanya, sehingga pengetahuan matematika dibangun atau dikonstruksi para siswa sendiri dan bukan ditanamkan oleh para guru. Para siswa harus dapat secara aktif mengasimilasikan dan mengakomodasi pengalaman baru ke dalam kerangka kognitifnya. Karenanya, pembelajaran matematika akan menjadi lebih efektif bila guru membantu siswa menemukan dan memecahkan masalah dengan menerapkan pembelajaran bermakna.

3. Untuk mengajar dengan baik, guru harus memahami model-model mental yang digunakan para siswa untuk mengenal dunia mereka dan penalaran yang dikembangkan dan yang dibuat para siswa untuk mendukung modelmodel itu. Karenanya, para guru harus mau bertanya dan mau mengamati pekerjaan siswanya. Setiap kesalahan siswa harus menjadi umpan balik dalam proses penyempurnaan rancangan proses pembelajaran berikutnya.

4. Pada konstruktivisme, siswa perlu mengkonstruksi pemahaman mereka sendiri untuk masing-masing konsep matematika sehingga peranan guru dalam mengajar bukannya "menguliahi", menerangkan atau upaya-upaya sejenis untuk memindahkan pengetahuan matematika pada siswa tetapi menciptakan situasi bagi siswa yang membantu perkembangan mereka membuat konstruksi-kontruksi mental yang diperlukan.

\section{F. METODE PEMBELAJARAN MATEMATIKA}


Tujuan pembelajaran matematika di jenjang pendidikan dasar dan pendidikan menengah adalah untuk mempersiapkan siswa agar sanggup menghadapi perubahan keadaan di dalam kehidupan dan di dunia yang selalu berkembang melalui latihan bertindak atas dasar pemikiran secara logis, rasional, kritis, cermat, jujur efisien, dan efektif (Puskur, 2002). Disamping itu, siswa diharapkan dapat menggunakan matematika dan pola pikir matematika dalam kehidupan sehari-hari dan dalam mempelajari berbagai ilmu pengetahuan yang penekanannya pada penataan nalar dan pembentukan sikap siswa serta ketrampilan dalam penerapan matematika.

Tujuan ini tidak akan tercapai jika siswa yang diajarkan matematika dengan cara konvensional (teacher center) karena dengan pembelajaran matematika secara konvesional, siswa menjadi pasif, dan tidak berkembang. Selain pembelajaran matematika yang dilakukan secara konvensional, media, bahan ajar, dan metode yang digunakan juga sangat minim. Hal ini jelas sangat berakibat buruk bagi perkembangan pendidikan matematika ke depan. Oleh karena itu, perubahan proses pembelajaran matematika yang menyenangkan harus menjadi prioritas utama, dan ini tidak lepas dari peran guru kelas di dalam mengembangkan cara mengajar matematika yang menyenangkan.

Matematika seharusnya dapat dipahami oleh semua orang dan malah menyenangkan, berguna dalam kehidupan sehari-hari (problemsolving, modeling), suatu permasalahan mungkin mempunyai lebih dari satu jawaban, atau malah mungkin tidak mempunyai jawaban sama sekali. Pandangan ini tentunya mengubah filsafat pendidikan matematika. Para dosen serta guru perlu memahaminya dan mempraktekan dalam pembelajarannya sehari-hari.

Berdasarkan kelemahan-kelemahan yangada dan tujuan masa depan yang ingin dicapai, ditemukan beberapa alternatif solusi untuk dilaksanakan sebagai proses pembelajaran matematika yaitu dengan menggunakan metode math magic, magic finger, kumon, sempoa, dan masih banyak lagi metode-metode lainnya. Metode-metode tersebut sesuai dengan perubahan paradigma pembelajaran, yaitu dari paradigma mengajar ke paradigma belajar atau perubahan paradigma pembelajaran yang berpusat pada guru ke paradigma pembelajaran yang berpusat pada siswa. Hal ini adalah salah satu upaya dalam rangka memperbaiki mutu pendidikan matematika. 
Proses pembelajaran yang baik tidak hanya diukur dari kuantitas pertemuan guru dan siswa saja, tetapi juga harus diukur dari mutu proses pembelajaran, seperti tingkat kesesuaian dengan kurikulum atau silabusnya, tingkat penguasaan materi oleh siswa, dan tingkat kepuasaan siswa terhadap proses pembelajaran, serta media pembelajaran yang mendukung proses pembelajaran. Dengan menggunakan metode math magic, sempoa, dan finger magic, matematika disajikan dalam bentuk permainan yang menyenangkan buat siswa dan tanpa memaksa siswa untuk belajar matematika.

Metode math magic, sempoa, dan finger magic adalah metode yang digunakan untuk merespon perubahan pembelajaran dari pembelajaran secara konvensional ke pembelajaran dengan menggunakan media yang menyenangkan siswa. Hal ini adalah salah satu upaya dalam rangka memperbaiki mutu pendidikan dan pembelajaran Matematika.

\section{PENUTUP}

Apa yang saya uraikan diatas adalah pengalaman saya dalam mempelajari matematika, mulai dari keengganan untuk belajar matematika sampai dengan benar-benar suka dalam mempelajari matematika. Pengalaman ini bukan sekadar pengalaman biasa yang penulis tuliskan, bukan pengalaman hidup yang di narasikan atau bahkan curahan hati yang dibukukan tetapi lebih dari itu yaitu pengalaman yang mempunyai referensi dan tahapan-tahapannya.

Tahapan-tahapan tersebut adalah:

1. Mengenal tokoh-tokoh sejarawan matematika

Dengan mengenal dan mengetahui tokoh-tokoh sejarawan matematika dan dengan mengetahui adanya sejarah matematika, maka akan menimbulkan kegairahan untuk mempelajari matematika dan menumbuhkan mental yang baik.

2. Mampu mengidentifikasi cara belajar matematika yang benar Dengan mengidentifikasi cara belajar matematika yang benar maka kita bisa mengetahui cara belajar matematika yang baik, apakah kita harus belajar rumus praktis atau konsep dasar matematikanya.

3. Mengetahui definisi dari matematika

Dengan mengetahui definisi matematika maka tidak akan ada lagi orang yang menganggap bahwa matematika hanya berkutat 
dengan angka, tetapi matematika adalah suatu bahasa yang universal.

4. Mengetahui karakteristik dan deskripsi dari matematika

Dengan mengetahui karakteristik dan deskripsi matematika maka kita akan tahu contoh-contoh matematika yang berbeda berdasarkan definisi dari matematika tersebut.

5. Mengetahui strategi pembelajaran matematika

Dengan mengetahui strategi pembelajaran matematika maka kita tidak akan takut lagi dengan matematika karena strategi yang digunakan dalam mempelajarai matematika sekarang bukan konvensional dan monoton yang menyebabkan kebosanan dalam mempelajari matematika, tetapi lebih atraktif dan menggunakan banyak permainan.

6. Mengetahui metode pembelajaran matematika

Dengan menggunakan metode pembelajaran matematika maka kita akan lebih cepat dalam menghitung operasi aljabar atau prosedur aritmetika.

\section{DAFTAR RUJUKAN}

1. Bodner, G.M. (1986). Constructivism: A theory of knowledge. Journal of Chemical Education. Vol. 63(10):873-878.

2. Joyce, B.; Weil, M.; Showers, B (1992). Models of Teaching (4th Ed). Boston : Allyn and Bacon

3. Nur, M. (2001). Realistic Mathematics Education. Jakarta: Depdiknas, Proyek PPM SLTP.

4. Orton, A (1987). Learning Mathematics. London: Casell Educational Limited

5. Smith, J.P. (1996). Efficacy and teaching mathematics by telling: a challenge for reform. Journal for Research in Mathematics Education. Vol 27(4) pp 387-402.

6. Tran Vui (2001). Practice Trends and Issues in the Teaching and Learning of Mathematics in the Countries. Penang: Recsam.

7. Boyer, Carl B (1968). A History of Mathematics. New York:John Wiley \& Sons, Inc.

8. Eves Howard (1964). An Introduction to the History of Mathematics. New York:Holt, Rinehart, \& Winston, Inc. 